\title{
Study of Recovering and Separating the Waste Metal Layers Aircraft by Electrochemical Treatment
}

\author{
Dihia Benyahia and Robert Hausler
}

\begin{abstract}
Recovery of waste metals of aircrafts is an important step during recycling process which is harder and more harmful by the presence of different toxic components. This study investigated the effects of different electrolyte ( $\mathrm{HCl}$, $\left.\mathrm{NaOH}, \mathrm{HNO}_{3}, \mathrm{H}_{2} \mathrm{SO}_{4}, \mathrm{H}_{3} \mathrm{PO}_{4}, \mathrm{NH}_{4} \mathrm{OH}\right)$ on the separation and recovery of waste metals layers using the electrochemical treatment with a constant voltage $3 \mathrm{v}$.In addition, the influence of electrolyte concentrations $(10,5,3,1) \mathrm{mol} / \mathrm{l}$ were studied after choosing the most effective electrolyte, the separation processes has been compared with and without electrochemical treatment. In order to analyze the micro structural of aircraft samples Scanning Electron Microscopy (SEM) equipped with Eds and opto-digital microscopy were used. The SEM images result shows that the aircraft waste contains seven layers, with different compounds. The major elements are Aluminum, chromium and titanium. It is observed hydrochloric acid has the best result on complete solving of the middle layer contains highest Aluminum element, so its solution release the other layers. The higher hydrochloric acid concentration and electrochemical process makes the separation of layers 14 times faster. The procedure was successfully separated and recovered three layers (aluminum layer chromium layer and titanium layer).The separation process can recover approximately $466 \mathrm{~kg}$ aluminum, $37 \mathrm{~kg}$ chromium and $138 \mathrm{~kg}$ titanium from 1 ton of waste metal.
\end{abstract}

Index Terms-Aircraft recycling waste metals, electrochemical treatment and hydrochloric acid, metal recovery.

\section{INTRODUCTION}

The average life of an airplane is approximately 30 years, furthermore 12,000 aircrafts will be out of service at next 20 years thus their storage is no longer a suitable solution, on the other hand the number of airplanes increase dramatically in the last decade [1], [2] so the aerospace industry needs an economical and ecological process for aircraft recycling which is applicable to a wide range of materials. The recycling will reduce the consumption of energy and environment pollution e.g. about 60 to $80 \%$ of the airplane structures consist of aluminum alloys, causing a total production of 192000 tons of aluminum in 2008. Recycling of aluminum will save energy and avoid toxic end mud during the aluminum production. On the other hand 10 tons of titanium production need about 10 days at 950 degree Celsius. Recycling of titanium compared to aluminum will save more energy because the energy required for titanium production is

Manuscript received September 25, 2015; revised November 13, 2015 This work was supported in part by the ETS University.

The authors are with the Superior School of Technology Québec University, Montreal, Canada (e-mail: dihia.benyahia.1@ens.etsmtl.ca, Robert.hausler@etsmtl.ca).
$50 \%$ higher than aluminum production [3].

The main process of recycling aluminum alloys which used by the previous researches is grinding and melting. This method requires about $5 \%$ of the energy producing new metal [1]-[4]. There is a few researches on the airplane waste metals. Recently AFRA (Aircraft Fleet Recycling Association) uses grinding and melting metal technique but with this process, the materials grinds without separating the coating which contains numerous hazardous and toxic metals (chromium) makes the processes too complex and time consuming [5]. The melting process requires $6000 \mathrm{kcal} / \mathrm{kg}$ energy for waste metal, high operation costs due to the large number of operations, and high pollution due to fumes and dross generated during the melting of the scrap [6].

The new researches propose some new methods for the recycling of aluminum alloys used Laser Induced Breakdown Spectroscopy (LIBS) method which is the only method to separate both cast and wrought aluminum into their individual alloys. The major limitation for the LIBS is that the surface of the aluminum scrap must be free of paints, lubricants or adhesives, since the pulse laser can only penetrate to a depth of $30 \AA$ or less on the surface of the aluminum [7], [8].

The other researches propose pressing and hot extrusion aluminum alloy by cold and hot pressing followed by hot extrusion but this method is expensive [9].

Color sorting is another method for alloy separating on the basis of their color as a result of chemical reaction a special solution. But this process cannot use to separate individual alloys within a family e.g. an alloy with high Zinc and low Copper concentration has a similar etching response as an alloy with high Copper and low Zinc contents [7]-[10].

The all new methods mentioned are expensive and not applicable for aerospace recycling industry.

The aim of this work is to propose a green process with the optimum parameters of performance, quality and cost. Many researches are proposed using electrochemical treatment for metal extraction using different acids and bases in waste water, soil, etc. Ref. [5]-[21] but there are a few researches in the aerospace industry. This research try to applicate the electrochemical treatment on waste metals of aircraft. The treatment will be used in order to separate and recover the different layers of aircraft waste metals.

\section{MATERIAL AND METHOD}

\section{A. Sample Preparation}

Some round specimen with diameter $2 \mathrm{~cm}$ are cut from a wing of airplane manufacture. Precise cutting is used to avoid deformation of samples during cutting process. 


\section{B. Microstructure Analysis}

One of samples is hot mounted by conductive resin for micro structural analysis as shown in Fig. 1. The specimen is polished by different abrasive papers and finishing by 1 micrometer diamond paste solution alumina suspension. Scanning Electron Microscopy (SEM) equipped by EDS was used to analyze and estimate the chemical composition, opto-digital Olympus microscope model DSX500 was used to observe the different layers and to determine their thickness.

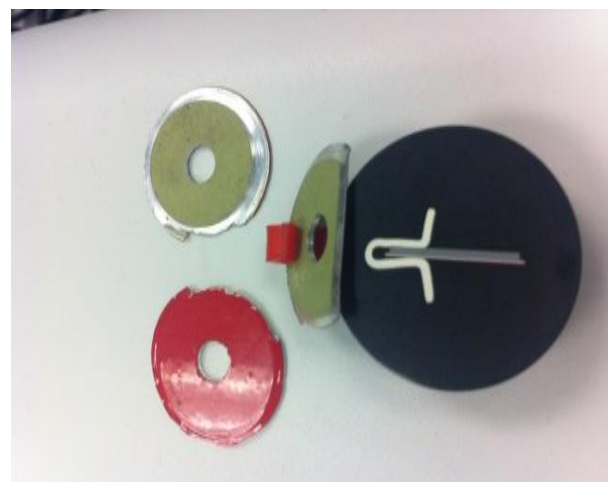

Fig. 1. The specimens and mounted sample.

\section{Chemical Process}

The electrolytic cell consisted of the rectangle steel cathode with dimension $2 \times 2 \mathrm{~cm}$ and sample as anode. Fig. 2 shows the electrochemical cell. The samples weight was $1.1 \mathrm{gr}$ before experiment. At the first step the research started with comparative study to compare the effect of different electrolytes on separation process such as Acids $(\mathrm{HCl}, \mathrm{HNO}$, $\mathrm{H} 2 \mathrm{SO} 4$ and $\mathrm{H} 3 \mathrm{PO} 4)$ and bases $(\mathrm{NH} 4 \mathrm{OH}$ and $\mathrm{NaOH})$. The volume of solution was $500 \mathrm{ml}$ contains acid or bases with concentration $3.3 \mathrm{~mol} / \mathrm{l}$. The experiments were done under room temperature with a constant voltage of $3 \mathrm{v}$. After choosing the best electrolyte, different electrolyte concentrations $(1 \mathrm{~mol} / 1,3 \mathrm{~mol} / 1,5 \mathrm{~mol} / 1$ and $10 \mathrm{~mol} / 1)$ are tested to find the optimum condition of process for separating different layers of materials.

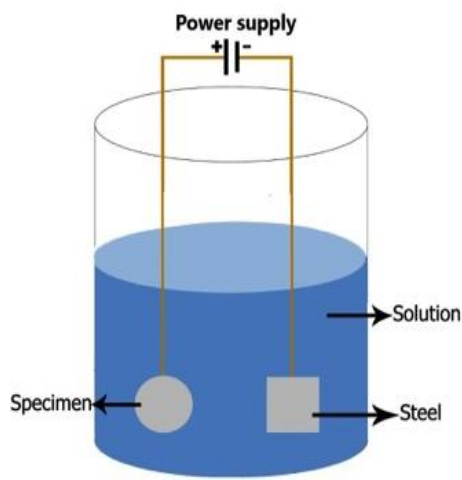

Fig. 2. Electrochemical cell.

\section{RESULTS}

The SEM image of different layers of sample is shown Fig. 3. The first and last layer are resin which is useless in this research. The thickness of each layer and its chemical composition are shown Table I and Fig. 4 respectively except the resin layers. The chemical composition is result of average of 3 different points of Edxin each layer. It is approximate results.

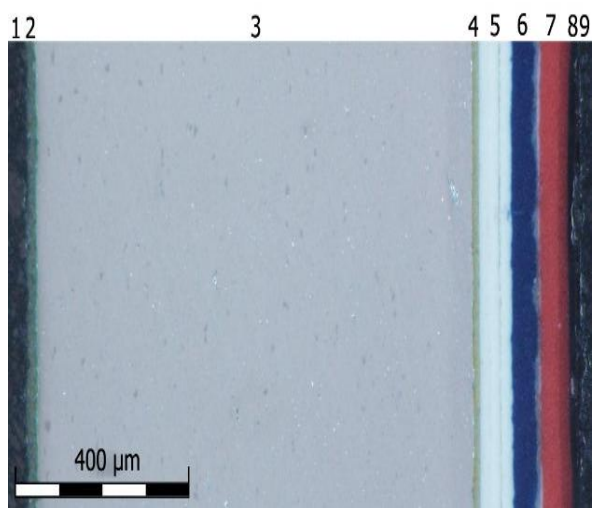

Fig. 3. The SEM image of different layers of sample.

TABLE I: THE THICKNESS OF LAYERS

\begin{tabular}{cc}
\hline \hline NO. LAYER & THICKNESS (MM) \\
\hline LAYER 2 & 28.137 \\
LAYER 3 & 991.220 \\
LAYER 4 & 15.536 \\
LAYER 5 & 77.744 \\
LAYER 6 & 59.120 \\
LAYER 7 & 74.63 \\
LAYER 8 & 27.965 \\
TOTAL THICKNESS & 1274,352 \\
\hline
\end{tabular}

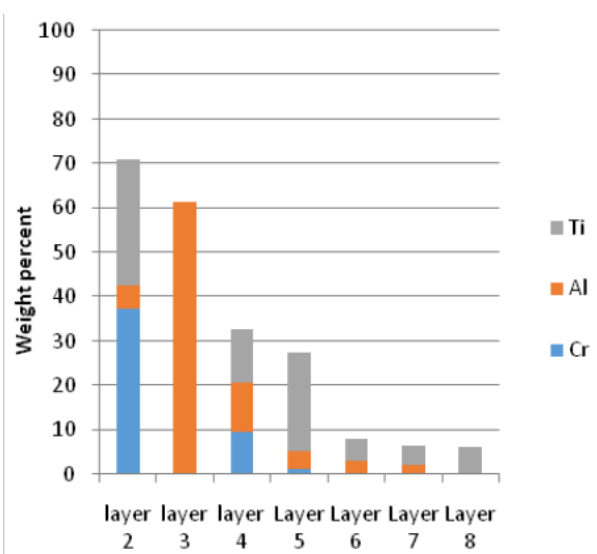

Fig. 4. The chemical composition of salmples layers before treatment.

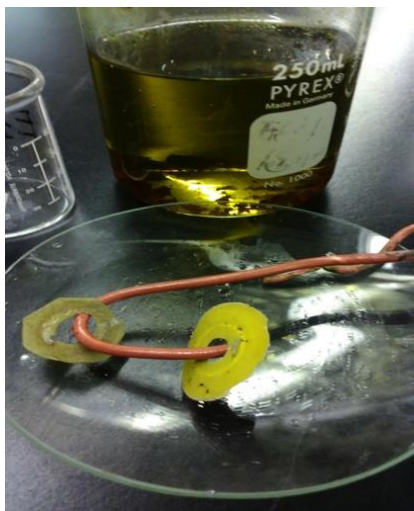

Fig. 5. The separated layers by the electrochemical process

The major element of layer 2 is chromium and it is called layer A for this research. The major element of layer 3 is aluminum which is called layer $\mathrm{B}$ and the major element of layers 4,5,6,7 and 8 is Titanium which is called layer $\mathrm{C}$. There are other elements such as Boron, Barium, Lead, magnesium, gold, silver, tantalum, Hafnium, Rhenium, etc in each layer but the focus is on the Chromium, Aluminum and Titanium in this research. 
During electrochemical process $\mathrm{HNO} 3, \mathrm{H} 2 \mathrm{SO} 4, \mathrm{H} 3 \mathrm{PO} 4$ and $\mathrm{NH} 4 \mathrm{OH}$ have a negligible separating effect during 24 hours. But $\mathrm{HCl}$ and $\mathrm{NaOH}$ can easily solve the middle layer and separate the other layers as shown in the Fig. 5. The Fig. 6 shows the chemical composition of each layer after separation treatment. The effect of $\mathrm{HCl}$ and $\mathrm{NaOH}$ electrolyte on separation process is shown in Table II.

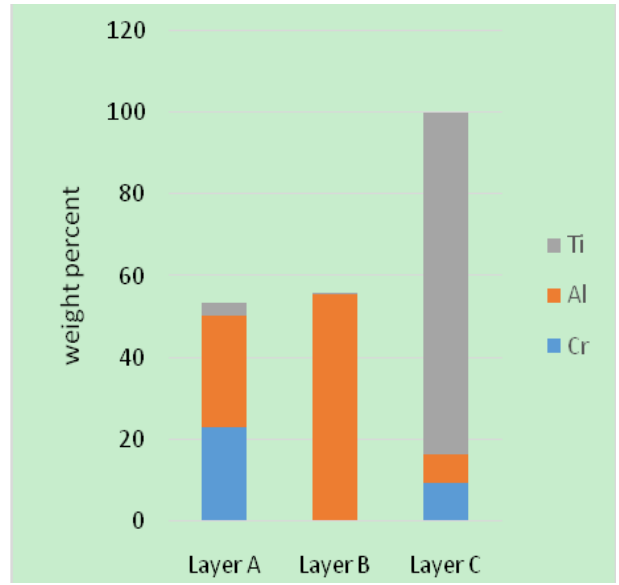

Fig. 6. The chemical composition of samples layers after treatment.

TABLE I: THE EFFECT OF ElECTROLYTES ON SEPARATION PROCESS

\begin{tabular}{lll}
\hline \hline Electrolyte & Time of separation & Results weight $(\mathrm{gr})$ \\
\hline \multirow{3}{*}{$\mathrm{HCl}$} & \multirow{2}{*}{$39 \mathrm{~min}$} & layer A: 0.07 \\
& & layer B: 0.86 \\
& layer C: 0.17 \\
$\mathrm{NaOH}$ & \multirow{3}{*}{13 hours } & layer A: 0.07 \\
& & layer B: 0.86 \\
& layer C: 0.17 \\
\hline \hline
\end{tabular}

The time of separation process and the weight of each layer after separation as a function of electrolyte concentration is shown in Table III.

The effect of Hydrochloric acid treatment on separation process with and without electrochemical treatment using acid concentration of $10 \mathrm{~mol} / \mathrm{l}$ was 0.5 hour and 7 hours respectively.

TABLE II: THE EFFECT OF ELECTROLYTE CONCENTRATION ON SEPARATION PROCESS

\begin{tabular}{ccccc}
\hline \hline $\begin{array}{c}\text { Concentration } \\
(\mathrm{mol} / \mathrm{l})\end{array}$ & $\begin{array}{c}\text { Time of } \\
\text { separation } \\
(\mathrm{min})\end{array}$ & $\begin{array}{c}\text { layer } \\
\text { Weight } \\
\text { A (gr) }\end{array}$ & $\begin{array}{c}\text { layer } \\
\text { Weight } \\
\mathrm{B}(\mathrm{gr})\end{array}$ & $\begin{array}{c}\text { layer } \\
\text { Weight C } \\
(\mathrm{gr})\end{array}$ \\
\hline 10 & 27 & 0.05 & 0.80 & 0.21 \\
5 & 35 & 0.06 & 0.79 & 0.23 \\
3 & 40 & 0.04 & 0.81 & 0.22 \\
1 & 49 & 0.05 & 0.82 & 0.23 \\
\hline \hline
\end{tabular}

\section{DISCUSSION}

Fig. 3 and Fig. 4 shows seven layers with different layer concentration which contain mostly chromium, aluminum and titanium and other elements. The layer $\mathrm{B}$ with highest aluminum is the middle layer so its solving will grantee its separation from left and right layers. Layers separating makes the recycling process easier, safer and more ecological. Table II shows that the hydrochloric acid separates the layers in shorter times than sodium hydroxide acid because of the affinity of chlorine with aluminum as the results shows good agreement with literature. The other electrolyte cannot separate the layers.

Table III shows higher concentration decrease the time required for separation process furthermore the process will be faster by electrochemical process so it is possible to use the electrochemical process for recycling. Also it will have cost, but it will save time, so it can decrease the total cost of process. It is recommended an economic study for the treatment process at future researches.

The separating process recovers about $466 \mathrm{~kg}$ aluminum from 1 ton of waste metal on the basis of weight percent that has been showed in Fig. 6.The resulting solution which contained solved aluminum can be used for water treatment, also it is possible to extract the aluminum from the solution [22], [23]. It recovers $37 \mathrm{~kg}$ chromium and $138 \mathrm{~kg}$ titanium, so it is possible to melt the chromium and titanium layers to make alloys. But for other recycling of chromium and titanium it is recommended to separate them for future research. Furthermore it is interesting topic for further research on the life cycle assessment to assess environmental impact of the process.

\section{CONCLUSION}

Different layers of waste metals from the wing of airplane has been separated by electrochemical treatment, using Hydrochloric acid. There are seven layers and their major elements are Aluminum, Titanium and chromium. The middle layers contains high content of aluminum thus solving this layer will release the surrounded layers. It is obtained that $\mathrm{HCl}$ with electrochemical has the most effective removal and recovery process between Acids $\left(\mathrm{HCl}, \mathrm{HNO}_{3}, \mathrm{H}_{2} \mathrm{SO}_{4}, \mathrm{H}_{3} \mathrm{PO}_{4}\right)$ and Bases $\left(\mathrm{NH}_{4} \mathrm{OH}\right.$ and $\left.\mathrm{NaOH}\right)$. Electrochemical makes the separation process about 14 times faster compare the process without electrochemical. The proposed method is cheap, fast, non-toxic and practical for aerospace industry. This method cannot separate the all of layers. For future researches it is proposed to develop this method to separate the rest of layers for higher efficiency of recovery.

\section{REFERENCES}

[1] AFRA. (2006-2015). Aircraft Fleet Recycling Association. [Online]. Available: http://www.afraassociation.org/

[2] J. Feldhusen, J. Pollmanns, and J. Heller, End of Life Strategies in the Aviation Industry, in Glocalized Solutions for Sustainability in Manufacturing, 2011, Heidelberg, Berlin: Springer, pp. 459-464.

[3] Y. S. Song, J. R. Youn, and T. G. Gutowski, "Life cycle energy analysis of fiber-reinforced composites," Composites Part A: Applied Science and Manufacturing, vol. 40, no. 8, pp. 1257-1265, 2009.

[4] A. P. Mouritz, Introduction to Aerospace Materials, Elsevier Science, 2012.

[5] E. Asmatulu, M. Overcash, and J. Twomey, "Recycling of aircraft: State of the art in 2011," Journal of Industrial Engineering, 2013.

[6] M. Samuel, "A new technique for recycling aluminium scrap," Journal of Materials Processing Technology, vol. 135, no. 1, pp. 117-124, 2003.

[7] A. Gesing and R. Wolanski, "Recycling light metals from end-of-life vehicle," JOM, vol. 53, no. 11, pp. 21-23, 2001.

[8] S. Bell, "Final report on scrap management, sorting and classification of aluminum," Natural Resources Canada Report, 2003.

[9] J. B. Fogagnolo, "Recycling of aluminium alloy and aluminium matrix composite chips by pressing and hot extrusion," Journal of Materials Processing Technology, pp. 792-795, 2003.

[10] P. B. Schultz and R. K. Wyss, Chemical Treatment of Aluminum Alloys to Enable Alloy Separation, 2000. 
[11] D. R. Sadoway, "New opportunities for metals extraction and waste treatment by electrochemical processing in molten salts," Journal of Materials Research, vol. 10, no. 3, pp. 487-492, 1995.

[12] A. Mittal et al., "Removal of Yellow ME 7 GL from industrial effluent using electrochemical and adsorption techniques," International Journal of Environment and Pollution, vol. 43, no. 4, pp. 308-323, 2010.

[13] S. Vasudevan, J. Lakshmi, and R. Vanathi, Electrochemical Coagulation for Chromium Removal: Process Optimization, Kinetics, Isotherms and Sludge Characterization, vol. 38, no. 1, pp. 9-16, 2010

[14] M. A. Barakat, "New trends in removing heavy metals from industrial wastewater," Arabian Journal of Chemistry, vol. 4, no. 4, pp. 361-377, 2011.

[15] K. Dermentzis et al., "Removal of nickel, copper, zinc and chromium from synthetic and industrial wastewater by electrocoagulation," International Journal of Environmental Sciences, vol. 1, no. 5, pp. 697-710, 2011.

[16] F. Fu and Q. Wang, "Removal of heavy metal ions from wastewaters: A review," Journal of Environmental Management, vol. 92, no. 3, pp. 407-418, 2011

[17] A. K. Golder et al., "Removal of hexavalent chromium by electrochemical reduction-precipitation: Investigation of process performance and reaction stoichiometry," Separation and Purification Technology, vol. 76, no. 3, pp. 345-350, 2011.

[18] M. P. Cervantes et al., "Conductive cement pastes with carbon fibers as anodes in the electrochemical chloride extraction," Int. $J$ Electrochem. Sci, vol. 10, pp. 3830-3840, 2015.

[19] T. Close et al., "Reversible oxygen scavenging at room temperature using electrochemically reduced titanium oxide nanotubes," Nat Nano, vol. 10, no. 5, pp. 418-422, 2015.

[20] A. Demir, S. Pamukcu, and R. A. Shrestha, "Simultaneous removal of $\mathrm{Pb}, \mathrm{Cd}$, and $\mathrm{Zn}$ from heavily contaminated mine tailing soil using enhanced electrochemical process," Environmental Engineering Science, vol. 32, no. 5, pp. 416-424, 2015.

[21] T. Zheng et al., "Research trends in electrochemical technology for water and wastewater treatment," Applied Water Science, p. 1-18, 2015.

[22] J. E. V. Benschoten and J. K. Edzwald, "Chemical aspects of coagulation using aluminum salts - I. Hydrolytic reactions of alum and polyaluminum chloride," Water Research, vol. 24, no. 12, pp. $1519-1526,1990$.

[23] S. Ghafari et al., "Application of response surface methodology (RSM) to optimize coagulation-flocculation treatment of leachate using poly-aluminum chloride (PAC) and alum," Journal of Hazardous Materials, vol. 163, no. 2-3, pp. 650-656, 2009.

Dihia Benyahia was born on April 6, 1992 in Algeria. She graduated from Nnational Industrial Hygiene and Safety Institute, Batna, Algeria in 2013. She achieved her license degree in environmental engineering processes; She has two certificates in health and safety, Nebosh certificate in the national examination board in occupational safety and health, England, (2012). IOSH certificate in institution of occupational safety and health, England, (2013). She is studying her M.A. degree in environmental engineering since 2014 in the Superior School of Technology Québec University, Canada.

Her current research include recycling of airplanes, the recovering of waste metals, separating different toxic metals for the economic and the ecologic process.

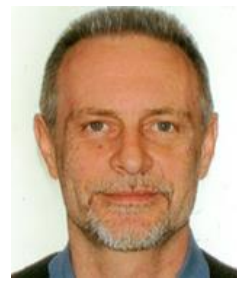

Robert Hausler was born on December 12, 1957 in Suiss. He achieved civil engineering environment Ph.D, Écolepolytechnique, Montreal, Canada (1990). civil engineering M.Sc.A, Montreal, Canada, (1984) chemistry B.SC, University of Genève, Suiss (1982). chemical engineering, B.Ing, School of Engineering Genève, Suiss, (1978). He is an associate professor at ÉTS, UQAM, Ecolepolytechnique, (1990-2015).

Dr. Robert is an expert on engineering and environmental chemistry, analysis of the cycles of life and sustainable development, management of environmental information, satisfaction analysis environmental projects, methods of treatment of industrial waste water and municipal, nanotechnology applied to environmental protection, application of the $4 \mathrm{R}-\mathrm{VD}$ for integrated waste management, reengineering of infrastructure networks in the context of urban ecosystems, cybernetic transport system (serpentine) urban. 